\title{
Bilateral Amyloidosis of the Oral Commisure Surrounding the Facial Artery
}

\author{
Joo-Hyung Lee ${ }^{1}$, Byung-Jun Cheon ${ }^{1}$, Jung-Uee Lee ${ }^{2}$ and Jin Choi ${ }^{1}$ \\ ${ }^{1}$ Department of Otolaryngology-Head and Neck Surgery, ${ }^{2}$ Pathology, The Catholic University of Korea College of Medicine, Seoul, Korea
}

안면동맥을 둘러싼 구각부의 양측성 아밀로이드증

이주형 $\cdot$ 천병준 $\cdot$ 이정의 ${ }^{2}$ 최 진 ${ }^{1}$

가톨릭대학교 의과대학 이비인후과학교실, ${ }^{1}$ 병리학교실 ${ }^{2}$

\author{
Received March 31, 2010 \\ Revised June 11,2010 \\ Accepted June 13, 2010 \\ Address for correspondence \\ Jin Choi, MD \\ Department of Otolaryngology- \\ Head and Neck Surgery, \\ The Catholic University of Korea \\ College of Medicine, 520-2 \\ Daeheung-dong, Jung-gu, \\ Daejeon 301-723, Korea \\ Tel $+82-42-220-9343$ \\ Fax $+82-42-221-9580$ \\ E-mail fishyello@naver.com
}

\begin{abstract}
Amyloidosis is a disease characterized by deposition of extracellular fibrillar proteins in various tissues mainly derived from the mesoderm. We experienced a case of a 59-year old man with a localized bilateral mass at the angle of the mouth, which was surgically removed. It surrounded the facial arteries bilaterally with the same pattern, and was diagnosed as amyloidosis pathologically. Followed by further workup, he was finally diagnosed with the multiple myeloma. Cases such as this where an amyloidosis mass surrounded the main branches of the facial arteries has not yet been reported in the literature. We present a case of localized amyloidosis at the oral commisure surrounding the facial arteries with the review of its clinical patterns, diagnostic tools, pathologic findings and treatment.
\end{abstract}

Korean J Otorhinolaryngol-Head Neck Surg 2010;53:452-5

Key Words Amyoidosis $\cdot$ Oral $\cdot$ Facial $\cdot$ Myeloma.
서 론

아밀로이드증은 부정형의 단백양 물질이 섬유소 형태로 세포 외에 침착되는 질환으로 조직학적 검사로 확진되며, 확 진 이후에는 아밀로이드증과 관련된 전신질환 유무를 조사 하게 된다. ${ }^{1-4)}$ 저자들은 아밀로이도증으로 진단된 양측 구 각부에 생긴 종괴를 주소로 내원한 환자를 경험하였으며, 종 괴는 양측 모두 안면동맥의 주행을 따라가며 동맥을 둘러 싸며 발생한 독특한 양상이었다. 이후 환자는 면역전기영 동검사와 골수조직검사 등의 추가검사를 통해 다발골수종 으로 최종 진단되었다.

안면부에 발생하는 아밀로이드증은 드물며 더우기 양측 성으로 구각부에 위치하며 안면동맥의 주행을 따라 성장하 는 형태의 아밀로이드증은 아직 보고된 바 없었기에 문헌 고찰과 함께 보고하는 바이다.

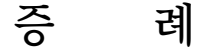

59세 남자 환자가 내원 6개월 전부터 커진 양측 구각부 의 무통성 종괴를 주소로 내원하였다. 환자는 1 년 전 악하 부 종괴를 주소로 본원 이비인후과를 내원하여 절제 및 생 검을 시행한 병력이 있었으며, 당시 조직검사상 지방괴사 와 근조직 퇴행 소견을 보였다. 그 후 환자는 양측 구각부 에 만져지는 종괴로 인하여 구음과 저작 곤란, 그리고 항상 알사탕을 물고 있는 듯한 모습의 미용상의 문제를 주소로 다시 본원을 외래를 방문하였다.

이학적 검사상 양측 구각부 주위로 단단하며 잘 경계가 지워지지 않는 약 $3 \times 3 \mathrm{~cm}$ 크기의 종괴가 촉진되었으며, 일부는 피부층 바로 아래에서 단단함이 촉진되었고, 혀에도 전반적인 경화 소견을 보였다. 또한 종괴의 성상은 1 년 전 의 악하부 종괴의 그것과 비슷하였다. 환자는 고혈압, 당뇨, 결핵 등의 전신질환의 병력은 없었으며, 술 전 시행한 혈액 학적 검사와 심전도검사, 흉부 방사선검사상에서 특이 소 
견을 보이지 않았다.

종괴에 대한 세침흡입검사상 양성양 세포(benign looking cells) 소견을 보였고, 조직학적 재진단과 기능적, 미용적 개 선을 목적으로 수술적 절제를 계획하였다.

수술은 국소마취하에 시행하었으며, 양측 모두 구각부 내 측의 협부 점막에 구각부와 평행하게 상하방향의 절개를 도 안하였다(Fig. 1). 종괴는 원형으로 단단하였으며, 안면부 피하층으로부터 쉽게 박리가 되는 부분도 있었으나, 어떤 부분은 안면근육층 또는 피하층으로 침윤되는 양상을 보여 쉽게 박리되지 않는 부분도 있었다. 반면 협부점막과는 비 교적 쉽게 박리가 되었다. 또한 종괴는 양측 모두 안면동 맥의 주행을 따라 안면 동맥을 둘러싸는 양상으로 존재하 였으며, 안면 동맥의 분지는 소작 또는 결찰하며 안면동맥

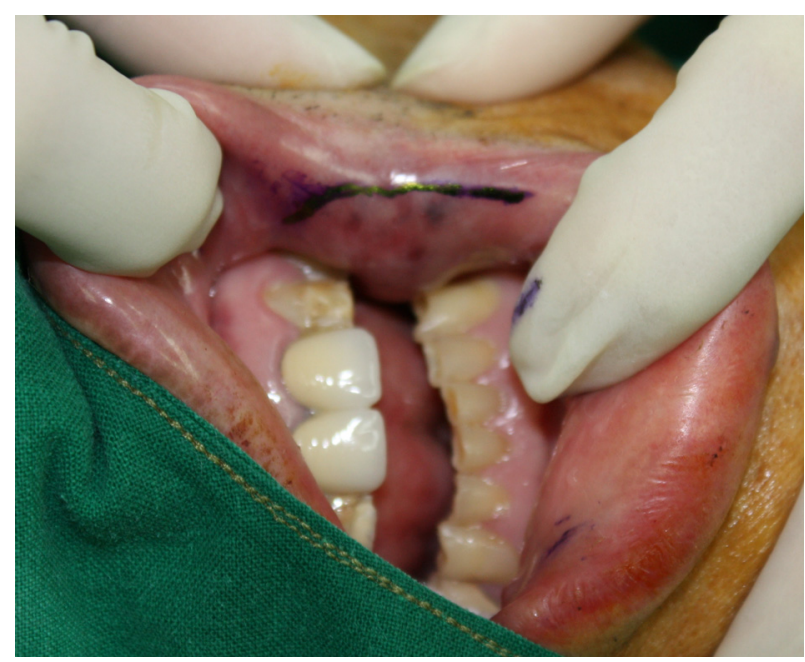

Fig. 1. Preoperative findings of the left-sided mass at the oral commisure. The mass bulges buccal mucosa and facial skin. Incision line was designed parallel with the lip margin.

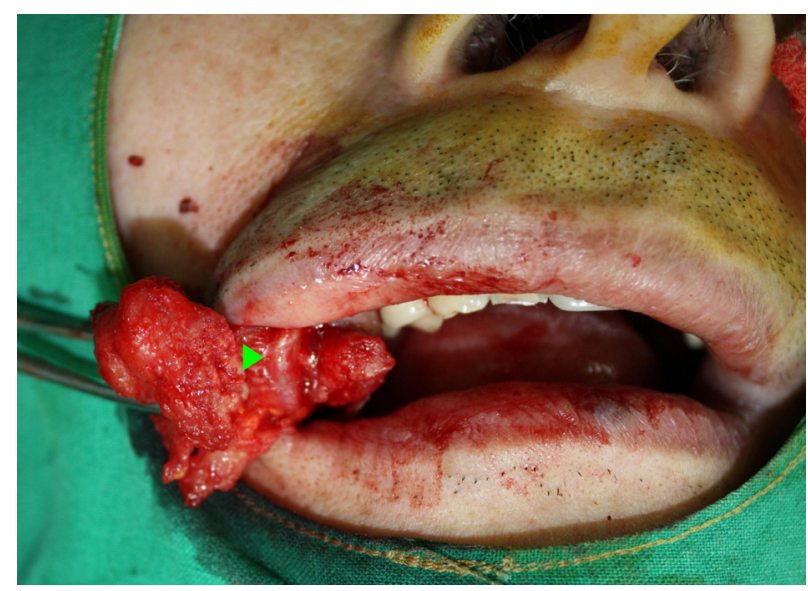

Fig. 2. Operative findings. The irregular surfaced mass at the right oral commisure infiltrating to the facial muscles and the subcutaneous tissue was removed preserving the main branch of the facial artery (arrowhead) surround by the mass.
의 주가지를 다치지 않도록 주의하며 종괴를 안면동맥으로 부터 분리하였다(Figs. 2 and 3).

이후 시행한 $\mathrm{H}-\mathrm{E}$ 염색 조직검사상 특징적인 호산성의 부정형 물질이 간질조직 내에 주위 근육조직까지 침범하는 양상으로 관찰되었으며(Fig. 4), 조직을 Congo red 염색한 이후 편광 현미경 관찰 시에는 녹색의 복굴절(apple green birefringence)이 관찰되어 아밀로이드증으로 확진할 수 있 었다(Fig. 5).

이후 다발골수종 혹은 류마티스 관절염, 결핵 등의 만성 염증성 질환의 기저질환 유무, 유전성 혹은 가족성 질환 여 부를 확인하기 위해 혈액과 소변 단백의 면역 전기 영동검 사, 류마티스양 인자, venereal disease research laboratory (VDRL) 검사, $\mathrm{C}$-reactive protein $(\mathrm{CRP})$ 를 포함한 임상

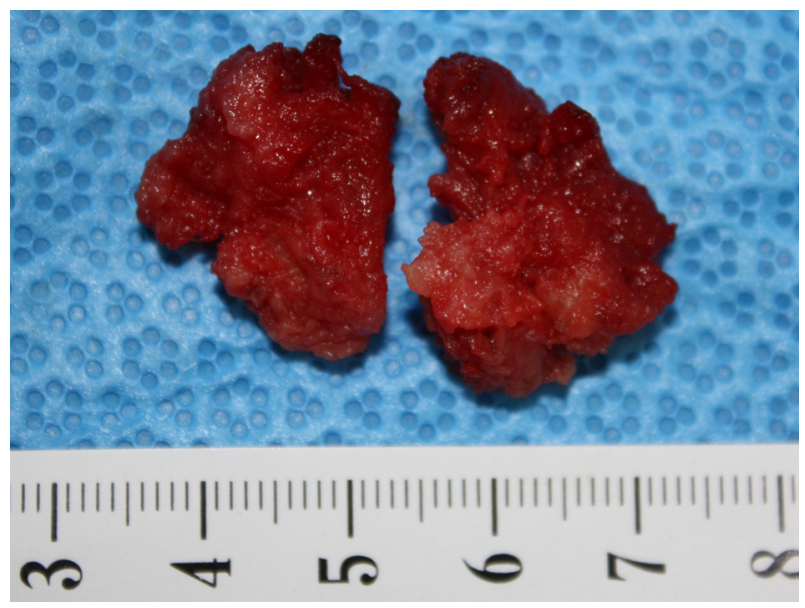

Fig. 3. Surgical specimen of the right-sided mass. The masses were divided into the two pieces through the line the which facial artery traversed. They were irregulary surfaced, lobulated, hard and pale yellowish colored. Some part of them were incorporated with the fibers of the facial muscles.

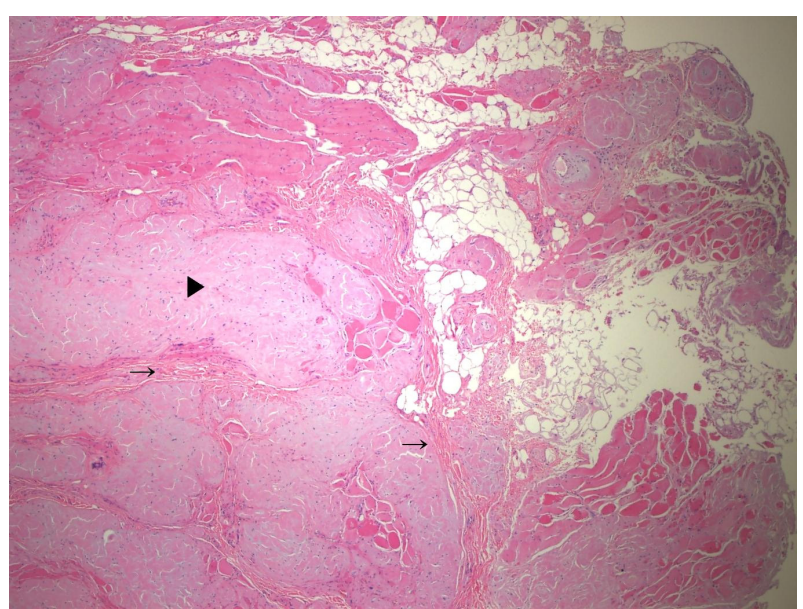

Fig. 4. Pathologic findings of the mass. Characteristic enosinophilic amorphous extracellular material (arrowhead) infiltrates into peripheral muscular tissue of the facial muscle (arrows)(H-E stain, $\times 2)$. 


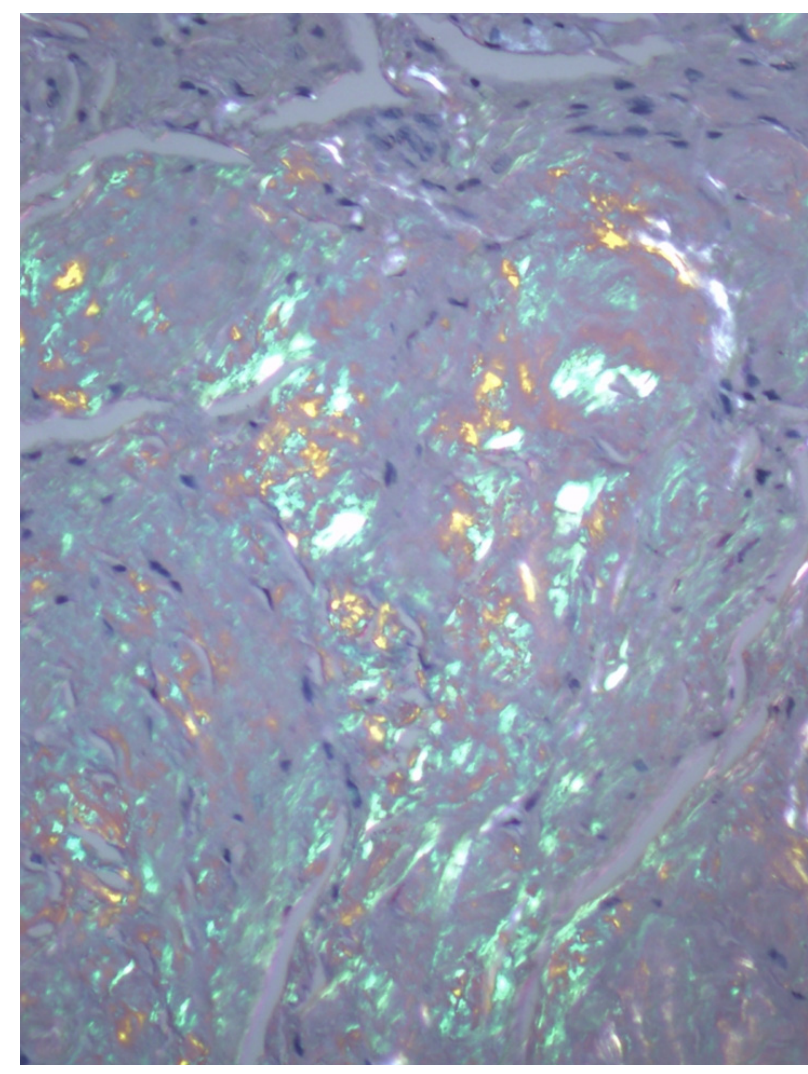

Fig. 5. Pathologic findings of the mass. It shows distinctive apple green birefringence which is a characteristic of the amyloidosis (Congo red stain, $\times 400$ ).

검사, 심초음파, 유전자검사를 시행하였다. 유전자검사, 심 초음파와 류마티스질환 관련 임상검사상에서는 특이 소견 이 관찰되지 않았으나, 면역전기영동검사상 카파형 단일클 론감마병증(monoclonal gammapathy, kappa type) 소견 을 보여 시행한 골수조직검사상 $23.2 \%$ 의 미성숙 형질세포 가 관찰되어 다발골수종(multiple myeloma)을 확진할 수 있었다.

환자는 혈액종양내과로 전원되어 6 차례의 고용량 경구스 테로이드 치료(Dexamthasone $20 \mathrm{mg} / \mathrm{day}$ for 4 days)를 받고, 현재까지 한 달에 4일간 Mephalan $10 \mathrm{mg} / \mathrm{day}$ 과 Prednisolone $60 \mathrm{mg} / \mathrm{day}$ 투여 받고 있으며, 수술 후 6개 월째 새로운 병변이 발생되지는 않은 상태이다.

\section{고 찰}

아밀로이드증은 조직 내에 부정형의 단백양 물질이 축적 되어 결절형의 종괴를 형성하는 질환으로, 병소는 국한성 으로 전신질환 없이 나타나거나 전신적 질환을 동반하여 국 한성 혹은 여러 장기를 침범하는 양상을 보이기도 한다. ${ }^{1-4)}$

조직학적 검사상의 특징은 $\mathrm{H}-\mathrm{E}$ 염색 시 부정형의 호산
성 물질이 간질조직에 침윤되는 양상으로 관찰되며, Congo red 염색한 조직을 편광현미경하에 관찰하면 녹색의 복굴 절(apple green birefringence)을 나타낸다. ${ }^{1-5,6)}$ 그 외에 Crystal violet 염색, Methyl violet 염색하에서는 이색성 (metachromasia)를 보이며, Periodic acid Schiff 염색에 는 자주색을 나타낸다. ${ }^{1-5,7)}$

아밀로이드증은 다른 전신성 선행질환 유무와 국한성 여 부에 따라 임상적 분류를 하게 되는데, 선행질환 없이 발 생하는 일차성 아밀로이드증, 다른 장기를 침범하지 않고 한 장기에만 관찰되는 국한성 아밀로이드증, 결핵, 류마티 스 관절염 등 전신질환과 관련된 이차성 아밀로이드증, 형 질세포질환(plasma cell dyscrasia)와 관련된 일차성 아밀 로이드증, 유전성 혹은 가족성 아밀로이드증의 5 종류로 구 분된다. ${ }^{1-4)}$ 본 증례는 다발골수종이 진단되었으므로 형질세 포질환(plasma cell dyscrasia) 와 관련된 일차성 아밀로이 드증으로 분류할 수 있다. 그 외에도 아밀로이드 원섬유를 구성하는 성분에 의한 분류법이 있다.5)

아밀로이드증은 조직학적 검사를 통해 확진할 수 있으며, 확진 이후에는 전신질환 여부를 확인하는 것이 매우 중요하 다. 다발 골수종 감별을 위한 혈액과 소변 단백에 대한 면 역전기영동검사가 필수적이며 필요에 따라 추가적으로 골 수조직검사를 시행할 수 있다. 류마티스질환, 교원 혈관질 환, 매독, 결핵 등과 같은 만성 질환 합병 여부를 확인하기 위해 자세한 병력청취와 함께 류마티스양 인자, VDRL, CRP 를 포함한 검사를 시행해야 한다. 아밀로이드증이 전신적 으로 침범되었는지를 확인하기 위해 흉부 방사선검사, 심 초음파, 복부초음파를 시행해야 하며, 그 외에 구순점막, 치 은점막, 복부지방조직, 직장점막의 조직검사를 추가 실시 할 수 있다. ${ }^{1-4)}$ 만약 이러한 광범위한 검사의 시행이 여의치 않을 경우에는 복부 지방의 흡인검사를 통한 조직검사가 전 신질환 유무를 확인하는 데 도움이 될 수도 있다. ${ }^{8)}$ 그 외에 도 유전성 혹은 가족성 질환과 관련이 의심되는 경우 유전 자검사를 시행하기도 한다. 본 증례에서도 상기한 검사들 을 시행했으며 안면부 외의 아밀로이드 침착을 보이는 장기 는 없었다.

아밀로이드증의 호발 부위로는 혀, 심장, 관절, 신장, 소화 기, 비장, 간, 피부, 신경계 등이 있으며,9) 두경부 영역에서 는 후두에서 가장 흔하게 발생하는 것으로 보고되었고, 국 내 문헌상으로도 일차성 후두 아밀로이드증은 4 예, 이차성 후두 아밀로이드증 1 예, 구개 편도에 발생한 예가 1 예, 비 인강 아밀로이드증 1 예가 각각 보고된 바 있다. ${ }^{1-4)}$ 그러나 안면 동맥을 둘러싸는 양상으로 발생한 구각부 아밀로이드 증은 희귀한 예로 아직 국내에서 발표된 적이 없다. 외국 문 
헌에서도 구강 주위 안면 동맥을 따라 발생한 아밀로이드 증이 발표된 예가 있으남) 이는 안면동맥에서 파생된 상하 순동맥(superior and inferior labial arteries)이 주된 병 변 부위로써, 본 증례와는 차이가 있다.

아밀로이드증이 전신질환 없이 국한성으로 나타나는 경우, 일차 병변을 완전히 제거하면 대체로 양호한 예후를 보인 다. ${ }^{11,12)}$ 본 증례와 같이 다발성 경화증이 동반된 아밀로이 드증의 경우 경구 Melphalan과 스테로이드 투여 또는 고용 량 Melphalan과 함께 줄기세포이식을 하는 것이 현재의 표준 치료로 받아들여지고 있다. ${ }^{8)}$

두경부와 안면부의 종양성 병변을 수술하는 이비인후과 의에게 조직검사 결과 중 가장 관심사는 악성 여부이다. 그 러나 본 증례에서와 같이 아밀로이드증은 세침흡입검사나 조직검사에서 악성 소견을 보이지 않으나 다발성 경화증과 같이 심각한 기저질환을 가질 수 있다는 점에서 염두에 두 어야 할 질환이라고 생각된다.

\section{REFERENCES}

1) Park CH, Kwon TK, Lee JH, Hong SJ. A case of nasopharyngeal amy- loidosis. Korean J Otolaryngol-Head Neck Surg 2007;50 (5) :456-9.

2) Koh JW, Yang HD, Chun JM, Lee JH. A case of localized amyloidosis of tonsil. Korean J Otolaryngol-Head Neck Surg 2001;44 (2):215-7.

3) Choi JS, Kim KS, Kim BS, Jang TJ. A case of laryngeal amyloidosis. Korean J Otorhinolaryngol-Head and Neck Surg 2009;52 (7):620-2.

4) Jin SM, Lee JH, Kim TH, Kim SH. A case of laryngeal amyloidosis. Korean J Otolaryngol-Head Neck Surg 2003;46 (8) :706-8.

5) Kennedy TL, Patel NM. Surgical management of localized amyloidosis. Laryngoscope 2000;110 (6):918-23.

6) Garrett JA. Amyloid deposits in the nose and maxillary sinuses. Report of a case. Arch Otolaryngol 1968;87 (4) :411-2.

7) Pentenerol M, Davico Bonino L, Tomasin C, Conrotto D, Gandolfo S Localized oral amyloidosis of the palate. Amyloid 2006;13 (1):42-6.

8) Comenzo RL. How I treat amyloidosis. Blood 2009;114 (15):3147-57.

9) Balatsouras DG, Eliopoulos P, Assimakopoulos D, Korres S. Primary local amyloidosis of the palate. Otolaryngol Head Neck Surg 2007; 137 (2):348-9.

10) Li MC, Chou G, Chen JT, Wong YK, Ho WL. Amyloidosis of medium-sized arteries presenting as perioral mass: a case report. Oral Surg Oral Med Oral Pathol Oral Radiol Endod 2003;95 (4) :463-6.

11) Alvi A, Goldstein MN. Amyloidosis of the palate. Otolaryngol Head Neck Surg 1999;120(2):287.

12) Tsai TL, Chu PY, Chang SY. Laryngeal amyloidosis with airway obstruction. Otolaryngol Head Neck Surg 2002;126 (3):329-30. 